\title{
Triple Open Dislocation in the Index Finger of the Hand Without a High-Energy Trauma
}

\section{Triple luxación abierta del segundo dedo de la mano tras traumatismo de baja energía}

\author{
María Amparo Fontestad Utrillas ${ }^{1}{ }^{10}$ Paúl Vicente Alonso de Armiño ${ }^{1}$ Marta Sancho Rodrigo $^{1}$ \\ ${ }^{1}$ Hospital General San Jorge, Huesca, Aragón, Spain \\ Address for correspondence María Amparo Fontestad Utrillas, MD, \\ Rev Chil Ortop Traumatol 2020;61:90-93. \\ Calle Ainielle, 13-1C. 22005 Huesca., Spain \\ (e-mail: amparofontestad@gmail.com).
}

\begin{abstract}
A simultaneous double dislocation (both proximal [PIP] and distal [DIP] interphalangeal joints) of a triphalangeal finger is a rare entity. The most common hand affected is the right hand. In the case of a closed triple dislocation (metacarpophalangeal [MCP], PIP

Palabras clave

- triple

- abierta

- luxación

- mano

Resumen

Keywords

- triple

- open

- dislocation

- hand and DIP joints); there are only two cases in the literature revised. In this case, we report an open triple dislocation in the index finger of the left-hand of a 54-year-old man treated by closed reduction and 3 weeks of immobilization followed by active mobilization with satisfactory results.

Level of evidence 3

La luxación simultánea de las articulaciones interfalángicas proximal (IFP) y distal (IFD) de un dedo de tres articulaciones es una rara entidad. La mano que es afectada con más frecuencia es la derecha. Con relación a una triple luxación cerrada (articulación metacarpofalángica [MCF], IFP e IFD), sólo hay descritos dos casos en la literatura revisada. En este caso, describimos una triple luxación abierta del segundo dedo de la mano en un varón de 54 años de edad tratada mediante reducción cerrada,e inmovilización durante 3 semanas seguida de movilización activa supervisada, con resultado final satisfactorio.

Nivel de Evidencia 3
\end{abstract}

\section{Introduction}

A simultaneous double dislocation (both proximal [PIP] and distal [DIP] interphalangeal joints) of a triphalangeal finger is a rare entity. ${ }^{1,2}$ The most common hand affected is the right hand. ${ }^{2}$ In the case of a closed triple dislocation (metacarpophalangeal [MCP], PIP and DIP joints); there are only two cases in the literature revised. ${ }^{3,4}$ In this case, we report an open triple dislocation in the index finger of the left-hand.

received

February 7, 2020

accepted

August 5, 2020
DOI https://doi.org/

10.1055/s-0040-1718452. ISSN $0716-4548$.

\section{Clinical Case}

A 54-year-old man with no significant medical history, falls to the floor down onto his left hand. The examination in the emergency department shows a swollen, painful finger with a dorsal displacement and a superficial wound without contact with the joint, on the volar aspect of the middle phalanx. There are no signs of tendon, vascular or nerve damage. The X-ray identifies a dorsal dislocation of the MCP and both the PIP and DIP joints (- Fig. 1).

Copyright $(2020$ by Thieme Publicações License terms Ltda, Rio de Janeiro, Brazil 


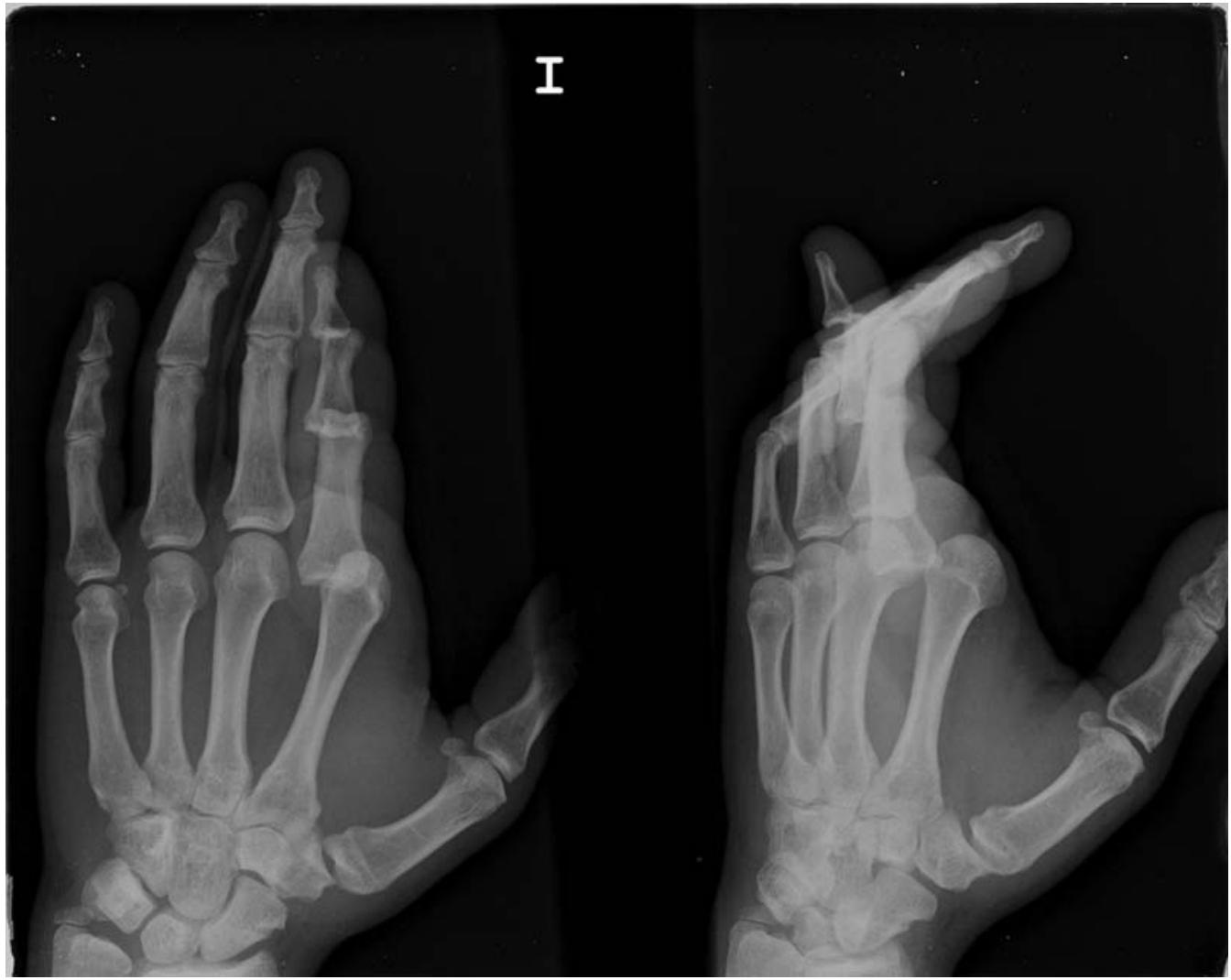

Fig. 1 First radiograph of the hand, showing a triple dislocation in the index finger.

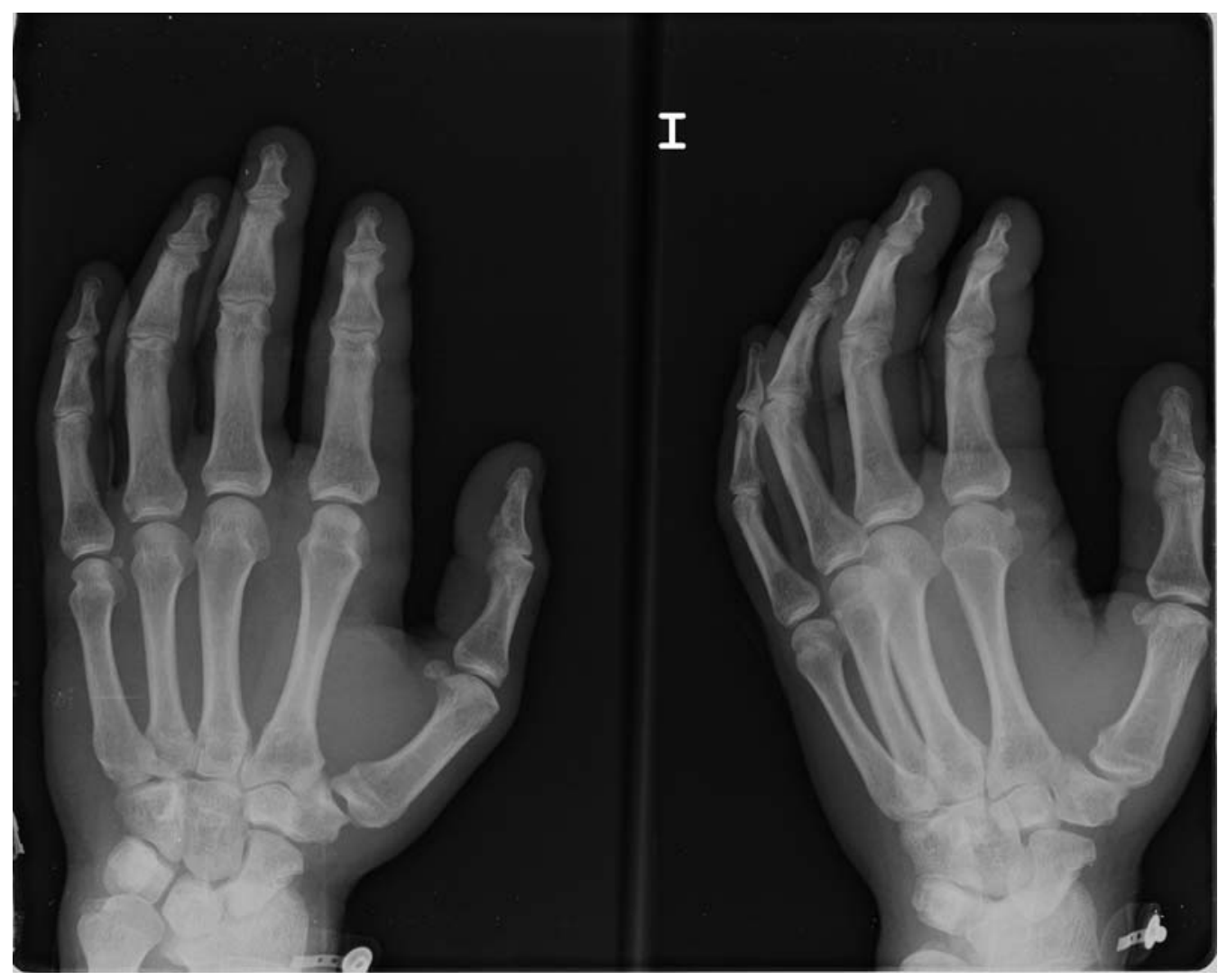

Fig. 2 Postreduction radiograph, demonstrating a correct reduction of the dislocation. 


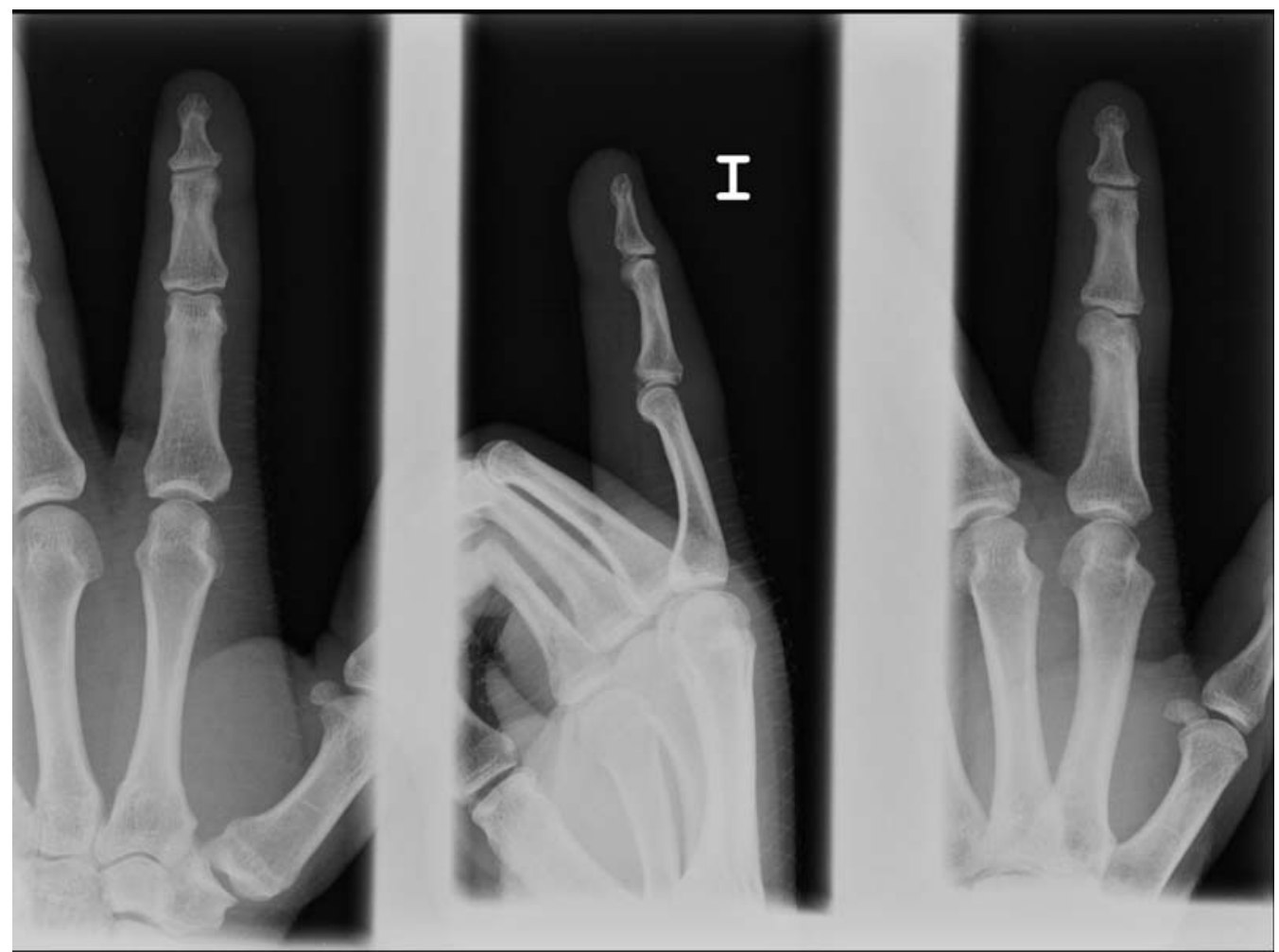

Fig. 3 Radiograph 3 months later.

Closed reduction under digital nerve block is performed. A posterior X-ray confirms the reduction ( $\mathbf{F i g . ~ 2 )}$ ) and, after cleaning and wound closure, the finger is immobilized with a splint in the 'intrinsecus plus' position for 3 weeks, followed by a syndactyly for 3 weeks, starting passive mobilization for 10 days and active mobilization after this.

The patient was examined 3 months after the injury (-Fig. 3). At that moment, he had no pain, full range of motion in the MCP with a lack of flexion of 10 degrees in the PIP joint and of 20 degrees in the DIP, with normal extension without instability and with normal finger and limb functionality. The patient is satisfied with the result, being able to carry out all the activities of his daily life.

\section{Discussion}

Bartels reported the first case of a double dislocation (PIP and DIP) in $1874 .^{5}$ In one case of double dislocation, this occurs in the DIP and the MCP. ${ }^{6}$ In the case of the thumb, only five cases have been reported in the English literature. ${ }^{6}$ There are only two cases reported of a triple dislocation. ${ }^{3,4}$

Usually, they are dorsal dislocations affecting most frequently the $4^{\text {th }}$ and $5^{\text {th }}$ finger of the right hand. It is more frequent in people with hiperlaxity or with a history of dislocation in this joint occurring mostly in young athletes after a high-energy trauma with the finger in hyperextension. . $2,4,7^{2}$

There is one case of combined dorsal DIP joint dislocation with volar MCP. ${ }^{8}$ Only in two cases of double dislocation, never in a triple dislocation, was an open injury. ${ }^{1}$ In the X-ray, the typical appearance is like a 'stepladder.' ${ }^{9}$
Because it is a rare injury, the treatment is not standardized. Closed reduction under a digital nerve block and immobilization in the 'intrinsecus plus' position for 3 weeks, no more, followed by a finger tape an intensive physiotherapy is acceptable, as it was done in the exposed case with good results. After the reduction, it is important to check the stability of the joint. ${ }^{1,3,9,10}$

Surgery may be necessary if an injury is associated with other lesions, such as a ruptured or interposition of the flexor tendon or the volar plate, a volar rim fracture of the phalanx ( $>30 \%$ of the articular surface), a ligament injury that causes instability, or a nerve injury, the latter only reported in the case of a triple dislocation. ${ }^{2,3,10}$

\section{Conflict of Interests}

The authors have no conflict of interests to declare.

\section{References}

1 Loupasis G, Christoforakis J, Aligizakis A. Simultaneous double interphalangeal dislocation in a finger. J Orthop Trauma 1998;12 (01):70-72

2 Kim YS, Song HS, Kim HM, Chung E, Park IJ. Simultaneous double dislocation of the interphalangeal joint in a finger. Arch Orthop Trauma Surg 2009;129(10):1387-1390

3 Hindley CJ. Triple dislocations in the index finger. J Trauma 1989; 29(01):122-124

4 Vidal N, Barrera-Ochoa S, Lluch A, Mir X. Simultaneous triple dislocation of the small finger. J Hand Surg Am 2013;38(01):206

5 Bartels M. Traumatische luxationen. Arch Klin Chir 1874; 16:636-654

6 Andersen MB, Andersen-Ranberg F. Dislocation of the distal interphalangeal and the metacarpophalangeal joints in the same finger: a case report. J Hand Surg Am 1995;20(04):574-575 
7 Takami H, Takahashi S, Ando M. Simultaneous double interphalangeal dislocation in one finger. Arch Orthop Trauma Surg 2000; 120(5-6):361-362

8 Panchal AP, Bamberger HB. Dorsal dislocation of the distal interphalangeal joint and volar dislocation of the metacarpophalangeal joint in the same finger: a case report. Hand (N Y) 2010;5(02): 200-202
9 Van Ransbeeck H, De Smet L. Double dislocation of both interphalangeal joints in the finger. Case report and literature review. Acta Orthop Belg 2004;70(01):72-75

10 Singh VK, Singh PK, Kalairajah Y. Open simultaneous double dislocation of the metacarpophalangeal and interphalangeal joints of the thumb with ulnar collateral ligament avulsion. Singapore Med J 2009;50(06):e206-e210 